\title{
Assessment of soil micronutrient level for vineyard production in southern Syria
}

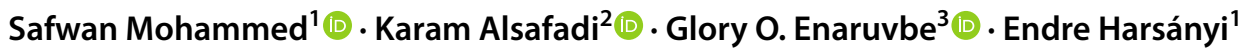

Received: 31 August 2020 / Accepted: 5 January 2021 / Published online: 21 January 2021

(c) The Author(s) 2021

\begin{abstract}
Availability of micronutrients is one of the important factors for the successful and economic cultivation of vineyards. The objectives of this study are to evaluate the spatial distribution of soil micronutrients $(\mathrm{Cu}, \mathrm{Fe}, \mathrm{Mn}, \mathrm{Zn}, \mathrm{B})$ and their suitability for vineyard cultivation in Jabal Al Arab of Syria. To achieve the research objectives, soil samples were collected randomly from vineyard farms which cover the study area. Following this, soil analyses were conducted to determine the concentration of soil micronutrients. Results showed that soil micronutrient concentrations did not reach the minimum threshold for vineyard cultivation with 1.1, 12.06, 11.2, 2.6 and $0.3 \mathrm{ppm}$ for $\mathrm{Cu}, \mathrm{Fe}, \mathrm{Mn}, \mathrm{Zn}$ and $\mathrm{B}$, respectively. Furthermore, spatial distribution showed that $63 \%, 39 \%, 34 \%, 76 \%$ and $74 \%$ of the study area was affected by severe deficiency of $\mathrm{Cu}, \mathrm{Fe}, \mathrm{Mn}$, Zn, B respectively.
\end{abstract}

Keywords Micronutrient deficiency $\cdot$ Vineyards $\cdot$ Soil mapping $\cdot$ Syria

\section{Introduction}

The increasing population pressure and higher demand for agricultural production have led to the adoption of more intensive agricultural system and the cultivation of more rapidly growing and higher yielding plants species in many parts of the world. Studies show that the intensification of agriculture production (i.e. industrialization of agriculture), coupled with unsustainable land management is causing tremendous degradation of soil quality, environment resources, and ecosystem services (Geertsema et al. 2016; Rojas et al. 2016; Matson et al. 1997; Kahsay et al. 2018). The degradation of soil resources is leading to severe consequences

Safwan Mohammed and Karam Alsafadi contributed equally to this work.

Safwan Mohammed safwan@agr.unideb.hu

1 Institute of Land Use, Technology and Regional Development, University of Debrecen, 4032 Debrecen, Hungary

2 Department of Geography and GIS, Faculty of Arts, Alexandria University, Alexandria 25435, Egypt

3 African Regional Institute for Geospatial Information Science and Technology, Obafemi Awolowo University, Ile-Ife, Nigeria including micronutrient deficiency in agricultural landscapes which can result in poor yield and low-quality crops (Alloway 2008). This is of critical concern for soil scientists, policy-makers, and conservation experts in ensuring sustainability of natural ecosystems, and food security (Rojas et al. 2016; Wubie and Assen 2020).

Arid and semi-arid regions account for more than $30 \%$ of the total earth surface (Liu et al. 2018). Agricultural intensification in this region pose a threat to agricultural systems and affects the terrestrial ecosystem especially soil quality. This has prompted various studies that aim to understand the processes affecting soil quality under agricultural practices in the region. For instance, studies have examined the impacts of salinization (Abd El-Hamid and Hong 2020; Abuelgasim and Ammad 2019); erosion (Preetha and AlHamdan 2019; Khademalrasoul and Amerikhah 2020), soil compaction (Abbaspour-Gilandeh and Abbaspour-Gilandeh 2019), and soil fertility reduction (Khresat et al. 2008) in the region. One commonly grown crop in arid and semi-arid regions is the grapevine which requires 16 soil nutrients to grow normally. These elements are classified as macronutrients and micronutrients (Burns 2012). Although plants require minute quantities of micronutrients, they play critical roles in different biochemical processes for healthy growth and yield. For instance, iron $(\mathrm{Fe})$ is essential for multiple functions in the plant, including electron transfer and 
chlorophyll synthesis (Chen et al. 2018), zinc (Zn) is crucial for plant enzyme systems (Mahmoud and Taha 2018), while $\mathrm{Mn}$ is important for redox processes (Amorós et al. 2018).

Grape cultivation is prevalent in many governorates of Syria, including Damascus, As-Suwayda, Deraa, Quneitra, Homs, Hama, Idlib and Aleppo, where it is considered an important economic crop (Al-Youssef et al. 2017, AlNasseer et al. 2006; Alsafadi et al. 2019). The cultivated area is about 47,000 ha with an estimated annual production of 213,000 tons in 2016 , which is equivalent to $0.34 \%$ of total global production (FAO 2018; Al-Nasseer et al. 2010, MAAR 2016). Since 1997, climate change and grape phylloxera (Daktulosphaira vitifoliae Fitch) have played a key role in the decline of grape production and the area under grape cultivation in Syria (Makee et al. 2004, 2008, 2010; Contaldo et al. 2011). Most of the grape-growing soil in Syria is classified as calcareous soil, which is deficient in micronutrients $(\mathrm{Cu}, \mathrm{Fe}, \mathrm{Mn}, \mathrm{Zn}, \mathrm{B})$. This type of soil is particularly abundant in private vineyards. Micronutrient deficiency is considered one of the most common abiotic stresses that affect Syrian grapevine production (Abu Nukta and Parkinson 2007; Sillanpää 1982; Abu Nukta 1995). For instance, Abu Nuqta and Bat'ha (2010) have reported extreme micronutrients deficiencies ranging from $14 \mathrm{ppm}$ for $\mathrm{Fe}, 1.8 \mathrm{ppm}$ for $\mathrm{Cu}, 2.3 \mathrm{ppm}$ for $\mathrm{Zn}$ and $0.54 \mathrm{ppm}$ for $\mathrm{B}$ in some private grapevine farms in the Draa governorate (S-Syria). Similarly, Jalab and Al-Sallom (2016) reported that some vineyards in the northeastern part of Syria suffer from chlorosis which is caused by iron deficiency due to a high soil content of $\mathrm{CaCO}_{3}$ and active lime. This shows that availability of soil micronutrients influences the growth and yield of vineyard in Syria.

Therefore, this study seeks to characterize the soil under vineyard cultivation in the western slopes of Jabal Al Arab, Syria, and determine the availability and deficiency of micronutrient for vineyards cultivation within the study area. This is important to help soil scientists and agronomists understand the nature of the soil and develop best land management practices that can help ameliorate the impacts of soil micronutrients deficiencies in the study area.

\section{Materials and methods}

\section{Study area}

The study was conducted in the southern part of Syria, in As-Suwayda governorate $\left(32^{\circ} 28^{\prime} 15^{\prime \prime} \mathrm{N}, 36^{\circ} 24^{\prime} 18^{\prime \prime} \mathrm{E}\right.$ and $32^{\circ} 46^{\prime} 44^{\prime \prime} \mathrm{N}, 36^{\circ} 45^{\prime} 15^{\prime \prime} \mathrm{E}$; Fig. 1). The study area is characterized by a Mediterranean climate with rainy cold winters and sunny summers. The mean monthly temperature range from 4 to $6{ }^{\circ} \mathrm{C}$ in January and from 28 to $30{ }^{\circ} \mathrm{C}$ in July, while average rainfall ranges between $350 \mathrm{~mm}$ in steep areas and $700 \mathrm{~mm}$ on the mountain top. The common soil orders are Vertisol, Entisols, and Inceptisols (Mohammed et al. 2020a). The main economic activity in the study area is agriculture, especially apples (Vitis sp.) and grapes (Malus silvestris). Other crops grown in the area include tomatoes (Lycopersicum Esculentum) and chick peas (Cicer Arictinum) (MAAR 2016).

\section{Soil data collection}

Data were collected based on land survey and field trips as previously reported by Mohammed et al. (2020b). Soil data were randomly collected from 55 soil profiles in soils under vineyard cultivation in the western slopes of Jabal AlArab (Fig. 1). Routine soil analysis was carried out using the methods outlined in Table 1.

\section{Assessment of micronutrients suitability for grapevine production}

As each soil profile consists of different horizons, and each one has a different value of micronutrient $(\mathrm{Cu}, \mathrm{Fe}, \mathrm{Mn}, \mathrm{Zn}$, B), we applied the weighting factor (Table 2) proposed by Sys et al. (1991) to assign each profile to a representative value for each micronutrient. This method was previously applied in the southern Syria by Mohammed et al. (2020c) and Alsafadi et al. (2019).

The recalculated values of the micronutrients were classified for vineyard suitability using Table 3 proposed by White (2009)

\section{Multivariate and spatial analysis}

Descriptive statistics (maximum, minimum, mean and slandered deviation) and principal components analysis (PCA) were analyzed using Statistical Package for The Social Science (SPSS) software (George and Mallery 2014). In this study, spatial distribution of soil micronutrient level $(\mathrm{Cu}$, $\mathrm{Fe}, \mathrm{Mn}, \mathrm{Zn}, \mathrm{B}$ ) was estimated using inverse distance weighting (IDW) interpolation algorithm. Although kriging techniques is also commonly used for spatial interpolation (Bocchi et al. 2000; Diodato and Ceccarelli 2004), IDW has the lowest mean error among the commonly used interpolation methods, when applied with highly variable spatial dataset (McGregor et al. 1998). Similarly, IDW is different from stochastic method (e.g., kriging) because it does not impose strict statistical assumptions on the data. The IDW assumes that each data point influences the resulting surface up to a finite distance (Phachomphon et al. 2010) and is usually applied to highly variable data as a moving average interpolator. The IDW method calculates an unknown point as a weighted average of known data samples within the local 
Fig. 1 The study area

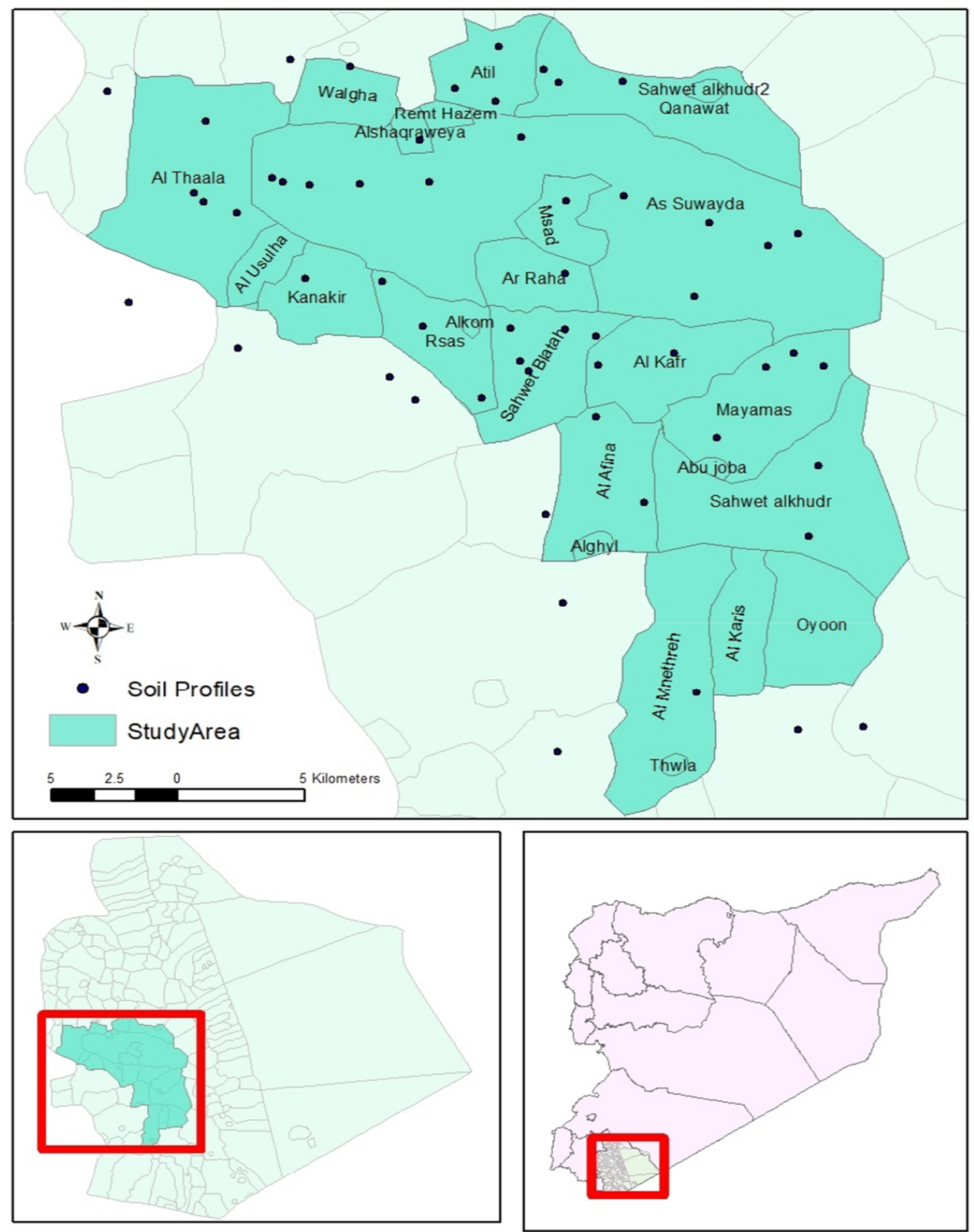

Table 1 Soil analysis methods

\begin{tabular}{lll}
\hline Soil characteristics & Method & References \\
\hline Soil texture & Hydrometer method & Grossman and Reinsch (2002) \\
Electrical conductivity (EC) & Digital EC meter (1:5) & Rhoades (1982) \\
Soil pH & Digital pH meter (1:2.5) & Melan (1982) \\
Organic matter & Wet digestion method & Nelson and Sommers (1982) \\
Calcium carbonates & Calcimeter method & Loeppert and Suarez (1996) (1996 \\
Cation exchange capacity & $\mathrm{NH}_{4}$ OAc extraction method & Polemio and Rhoades (1977) \\
Calcium and magnesium & Titration method & Suarez (1996) \\
Potassium and sodium & Flame photometer & Helmke and Sparks (1996) \\
Available Fe, Cu, Mn, and $\mathrm{Zn}$ & DTPA extraction method & Lindsay and Norvell (1978) \\
Available boron & Colorimetric method & Gupta (1967) \\
\hline
\end{tabular}


Table 2 Weighting factor classification (Sys et al. 1991)

\begin{tabular}{lll}
\hline Depth $(\mathrm{cm})$ & Section number & Weighting factor \\
\hline $125-150$ & 6 & $2-1.5-1-0.75-0.5-0.25$ \\
$100-125$ & 5 & $1.75-1.5-1-0.5-0.25$ \\
$75-100$ & 4 & $1.75-1.25-0.75-0.25$ \\
$50-75$ & 3 & $1.5-1-0.75$ \\
$25-50$ & 2 & $1.25-0.75$ \\
$0-25$ & 1 & 1 \\
\hline
\end{tabular}

surrounding surface. The algorithm can be expressed by Eq. (1) below (Uygur et al. 2010; Guan et al. 2017).

$R_{x}=\frac{\sum_{l=1}^{m} z(x) d_{i j}^{-r}}{\sum_{l=1}^{m} d_{i j}^{-r}}$,

where $z(x)$ is known data samples within a chosen neighborhood, $r$ is the weight and $d_{i j}$ is the distance between the predicted point and the measured point, $m$ is the number of the neighboring observations samples used for prediction. In this study, data of 16 points samples and the weight power of 1 were used because the weight power of one has been shown to perform better than powers of 2, 3 and 4 if the skewness is below than 1 value (Liu et al. 2012; Robinson and Metternicht 2006; Guan et al. 2017). The inverse distance weighting (IDW) was applied via a GIS environment using the geostatistical analyst tool of ArcGIS 10.8 to generate spatial distribution patterns of the soil micronutrients.

\section{Results}

\section{Soil characteristics in the study area}

Soil characteristics reflect soil development stage, which could help to determine the suitability of soil for agricultural purposes. In the study area, the soil depth was mostly less than $150 \mathrm{~cm}$, depending on the geographical position of the soil profile (backslope, foot-slope). Soil texture ranged between clay and silty clay in most of the studied profiles, where clay content increasing gradually with depth. This could be due to in situ clay formation or due clay migration (Mohammed et al. 2020a). Calcium carbonates did not exceed $18.4 \%$ in the majority of the studied locations; similarly, EC did not exceed $2.8 \mathrm{ds} / \mathrm{m}$, which indicates low soil salinity in the study area (Table 4).

Furthermore, the studied profile was characterized by low organic matter content because of intensive land use and high mineralization of plant residue. The soil reaction $(\mathrm{pH})$ ranged between moderate $(\mathrm{pH}$ 6.5) and weak alkalinity (pH 8.1), which can be explained by the moderate calcium carbonate content, low organic matter content (OM\%), and domination of smectite clay minerals. The cation exchange capacity (CEC) was relatively high, reflecting the high clay content of the soil which reached an average of 50 mmeq/100 g soil. Among the exchangeable cations, $\mathrm{Ca}$ dominates in the soil adsorption complex, followed by $\mathrm{Mg}$, $\mathrm{K}$, and $\mathrm{Na}$ in that order.

The soils were relatively poor in micronutrients $(\mathrm{B}, \mathrm{Fe}$, $\mathrm{Zn}, \mathrm{Mn}$ and $\mathrm{Cu}$ ) and their concentration decreased with depth. This is attributed to the low levels of these nutrients in the parent material, fixation in the soil, and plant uptake (Table 4).

Table 4 Statistical analyze of some soil properties in the study area

\begin{tabular}{lcccll}
\hline Soil characteristics & $n$ & $\bar{x}$ & \multicolumn{1}{c}{$S_{x}$} & Max & Min \\
\hline Depth (cm) & 56 & 93.66 & 22.59 & 150 & 20 \\
$\mathrm{pH}_{\mathrm{H}_{2} \mathrm{O}}$ & 56 & 7.44 & 0.376 & 8.1 & 6.5 \\
$\mathrm{EC}(\mathrm{ds} / \mathrm{m})$ & 56 & 0.16 & 0.38 & 2.8 & 0 \\
$\mathrm{OM} \%$ & 56 & 0.96 & 0.89 & 6.8 & 0.3 \\
$\mathrm{CaCO}_{3} \%$ & 56 & 3.87 & 4.36 & 18.4 & 0 \\
$\mathrm{CEC}^{(m}$ meq/100gsoil) & 56 & 42.3 & 6.7 & 55.8 & 19.4 \\
$\mathrm{Sum}(\mathrm{ppm})$ & 56 & 37.98 & 6.46 & 50.70 & 6.40 \\
$\mathrm{~B}(\mathrm{ppm})$ & 56 & 0.37 & 0.43 & 1.66 & 0.02 \\
$\mathrm{Fe}(\mathrm{ppm})$ & 56 & 12.06 & 10.63 & 75.5 & 2.82 \\
$\mathrm{Zn}(\mathrm{ppm})$ & 56 & 2.61 & 1.54 & 6.986 & 0.10 \\
$\mathrm{Mn}(\mathrm{ppm})$ & 56 & 11.20 & 11.60 & 73.6 & 1.61 \\
$\mathrm{Cu}(\mathrm{ppm})$ & 56 & 1.18 & 0.66 & 4.15 & 0.19 \\
\hline
\end{tabular}

$\bar{x}$ : average, $S_{x}$ : standard deviation

${ }^{\text {a }}$ Sum of basic cations $\left(\mathrm{Ca}^{2+}+\mathrm{Mg}^{2+}+\mathrm{K}^{+}+\mathrm{Na}^{+}\right)$
Table 3 Micronutrient level classification for grapevines (White 2009)

\begin{tabular}{lllll}
\hline Micronutrient & Deficient $(\mathrm{ppm})$ & $\begin{array}{l}\text { Low to marginal } \\
(\mathrm{ppm})\end{array}$ & Adequate (ppm) & $\begin{array}{l}\text { High to } \\
\text { excessive } \\
(\mathrm{ppm})\end{array}$ \\
\hline $\mathrm{Fe}$ & - & $<25-30$ & $>30$ & - \\
$\mathrm{Cu}$ & $<3$ & $3-5$ & $6-11$ & $>40$ \\
$\mathrm{Zn}$ & $<15$ & $15-25$ & $26-150$ & $>450$ \\
$\mathrm{Mn}$ & $20-29$ & $30-60$ & $>500$ \\
$\mathrm{~B}$ & $<20$ & $25-34$ & $35-70$ & $>100$ \\
\hline
\end{tabular}


Table 5 Correlation matrix between studied micronutrients

\begin{tabular}{llllll}
\hline & $\mathrm{Cu}$ & $\mathrm{Fe}$ & $\mathrm{Mn}$ & $\mathrm{Zn}$ & $B$ \\
\hline $\mathrm{Cu}$ & 1 & & & & \\
$\mathrm{Fe}$ & $0.688^{* *}$ & 1 & & & \\
$\mathrm{Mn}$ & $0.604^{* *}$ & $0.876^{* *}$ & 1 & & \\
$\mathrm{Zn}$ & 0.260 & -0.095 & -0.117 & 1 & \\
$\mathrm{~B}$ & $-0.267^{*}$ & 0.129 & $0.313^{*}$ & $-0.377^{* *}$ & 1 \\
\hline
\end{tabular}

*Correlation is significant at the 0.05 level

**Correlation is significant at the 0.01 level

To further investigate the relationship between micronutrients, multivariate data analysis was carried out (Table 5). There was a significant positive correlation $(p<0.01)$ between $\mathrm{Fe}$ soil content and both of $\mathrm{Cu}(0.68)$ and $\mathrm{Mn}$ soil content $(0.87)$. Also, there was a significant positive correlation between $B$ soil content and Mn (0.31) $(p<0.05)$. Interestingly, the study showed a negative significant correlation between $\mathrm{B}$ and both of $\mathrm{Cu}(0.26)$ $(p<0.05)$, and $\mathrm{Zn}(0.37)(p<0.01)$.

Furthermore, principal components analysis (PCA) was applied to extract the type of correlation structure among micronutrients (Table 6). The first three component explained $92 \%$ of the total variance. The first principle component (PC1) explained $49.248 \%$ of the total variance which was dominated by $\mathrm{Fe}, \mathrm{Mn}$ and $\mathrm{Cu}$ (Table 7). While the second principle component (PC2) explained $31.753 \%$ and dominated by B and $\mathrm{Zn}$ (Table 7).

\section{Availability and deficiency of micronutrient for vineyards cultivation}

By applying IDW method, Fig. 2 depicts the spatial distribution of the evaluated micronutrients within the study area. The concentration of B was higher in the southern part (1-1.5 ppm); while the concentration did not exceed $0.25 \mathrm{ppm}$ in the northern part (Fig. 2a). Similarly, the concentration of available $\mathrm{Fe}$ was higher in the southern part (7.5-25 ppm) (Fig. 2b). Zinc and Manganese show similar spatial pattern with the highest concentration occurring in the eastern portion of the study area (Fig. 2c, d). The northern part of the study area, however, shows a higher concentration of copper (5-6.98 ppm) than the northern part which was mostly less than 2 ppm (Fig. 2e).

Table 3 showed that the soil is deficient in micronutrients, which makes it unsuitable for vineyard cultivation, as can be seen in Fig. 3.

\section{Discussion}

In this study, 55 soil profiles were investigated in the southern part of Syria to assess the suitability of micronutrient level for vineyard cultivation. Results reveal that micronutrient levels were not adequate for vineyard production (Table 4). The spatial distribution of micronutrient level suitability for vineyards showed that most of the western and southern parts of the study area were affected by severe deficiencies of $\mathrm{Cu}, \mathrm{Fe}, \mathrm{Mn}$, Zn, B (63\%, 39\%, 34\%, 76\%, and 74\%, respectively) (Fig. 3). This result is consistent with findings reported by Abu Nukta (1995) who observed that iron, zinc, and boron were especially deficient in soils under vineyards in southwestern Syrian.
Table 6 Total variance explained by factor analysis

\begin{tabular}{llllllll}
\hline \multirow{2}{*}{ Component } & \multicolumn{2}{l}{ Initial eigenvalues } & & \multicolumn{3}{l}{ Extraction sums of squared loadings } \\
\cline { 2 - 3 } & Total & Variance $\%$ & Cumulative $\%$ & & Total & Variance \% & Cumulative \% \\
\hline 1 & 2.462 & 49.248 & 49.248 & & 2.462 & 49.248 & 49.248 \\
2 & 1.588 & 31.753 & 81.001 & & 1.588 & 31.753 & 81.001 \\
3 & 0.639 & 12.787 & 93.788 & & & \\
4 & 0.208 & 4.169 & 97.957 & & & & \\
5 & 0.102 & 2.043 & 100 & & & & \\
\hline
\end{tabular}

Table 7 The micronutrients and factors using varimax rotation method

\begin{tabular}{|c|c|c|c|c|c|c|}
\hline \multirow[t]{2}{*}{ Elements } & \multicolumn{3}{|c|}{ Before rotation } & \multicolumn{3}{|c|}{ After rotation } \\
\hline & 1 & 2 & 3 & 1 & 2 & 3 \\
\hline $\mathrm{Fe}$ & 0.955 & -0.050 & -0.070 & 0.951 & 0.073 & -0.097 \\
\hline Mn & 0.938 & -0.194 & 0.098 & 0.916 & 0.290 & -0.068 \\
\hline $\mathrm{Cu}$ & 0.804 & 0.471 & -0.099 & 0.840 & -0.345 & 0.233 \\
\hline B & 0.147 & -0.836 & 0.499 & 0.062 & 0.964 & -0.191 \\
\hline $\mathrm{Zn}$ & -0.032 & 0.791 & 0.605 & -0.005 & -0.184 & 0.980 \\
\hline
\end{tabular}




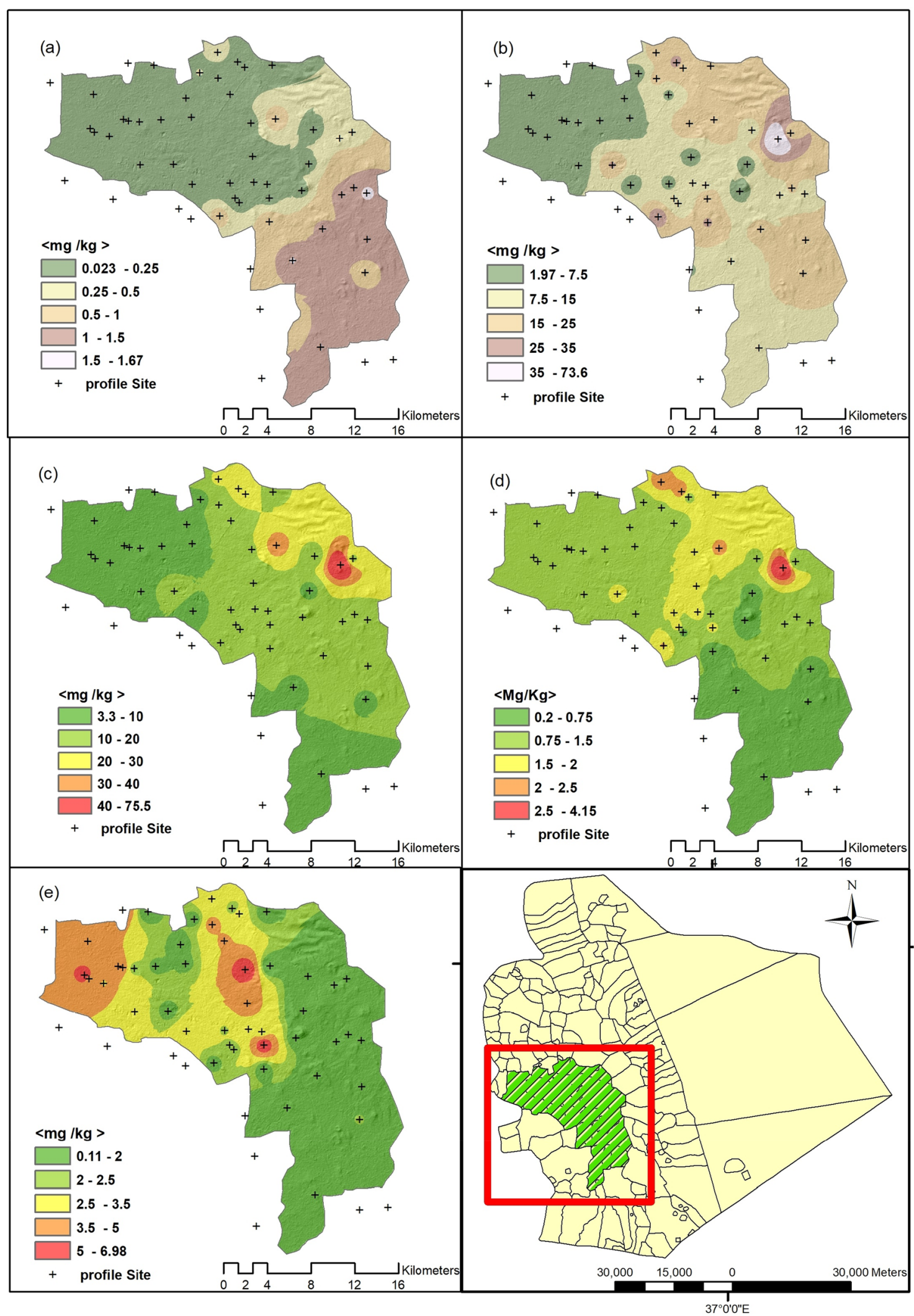

Fig. 2 Distribution maps of micronutrient concentration in the study area: a $B ; \mathbf{b} \mathrm{Fe} ; \mathbf{c} \mathrm{Zn} ; \mathbf{d ~ M n} ; \mathbf{e ~ C u}$ 


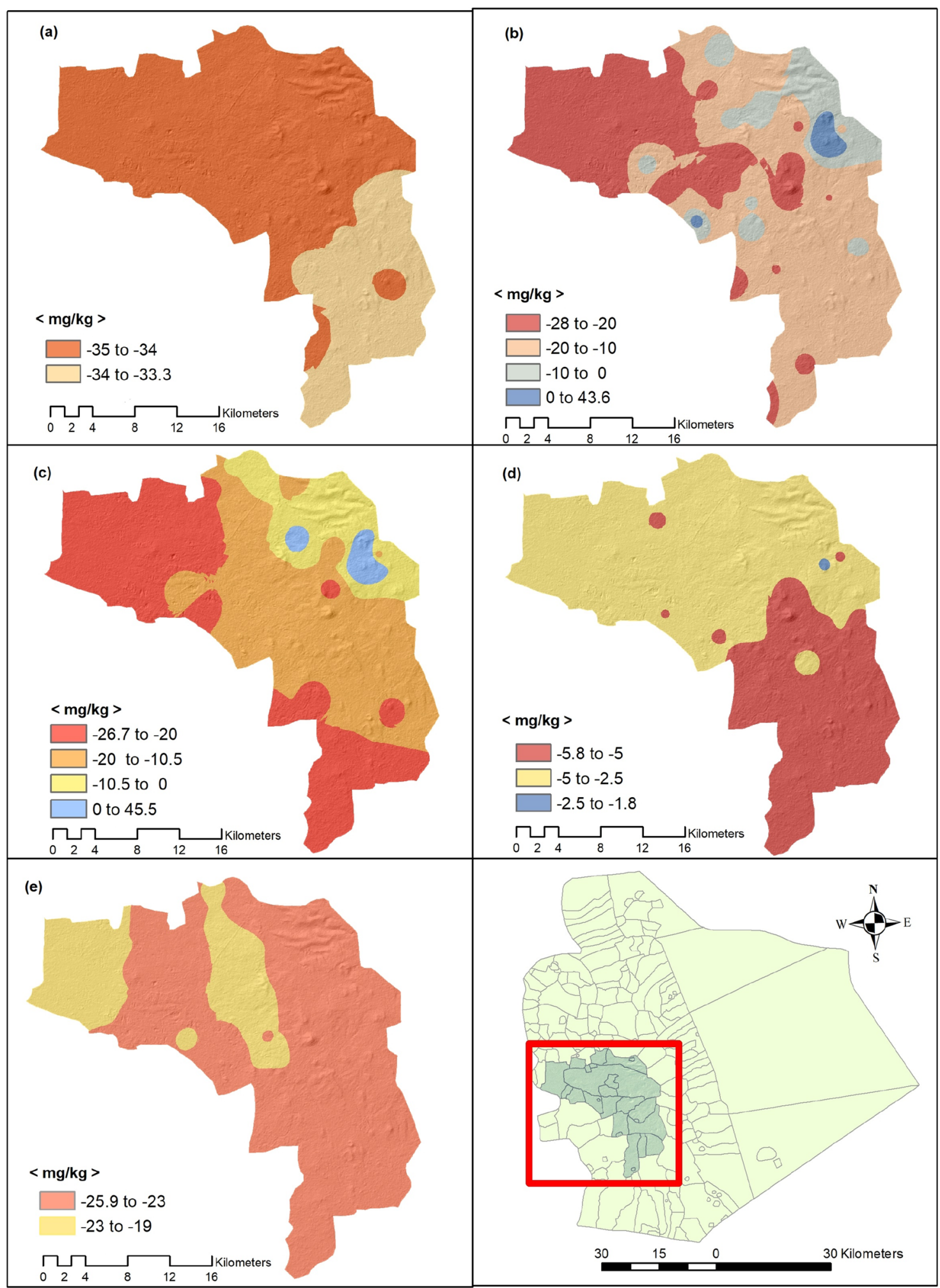

Fig. 3 Distribution maps of micronutrient deficit for vineyards cultivation in the study area: a $B$; $\mathbf{b}$ Fe; $\mathbf{c} \mathrm{Zn} ; \mathbf{d ~ M n ; ~ e ~ C u ~}$

Many studies show that micronutrient availability in Syrian ranges from moderate to low (Hennawi and Habib 2012; Kiwan et al. 2014). In addition, Alloway (2004) indicated that the available $\mathrm{Zn}^{2+}$ in the Syrian is not optimum for agricultural production. The low micronutrient concentration in Syrian soils may be because of the alkalinity of the soil (Sillanpää 
1982), high calcium carbonate, the intensity of vineyard cultivation (Amorós et al. 2018), the mineralogical composition of the parent material (Kiwan et al. 2014), and topographical characteristics (Hennawi and Habib 2012).

Micronutrient availability in the soil is generally affected by many factors, including $\mathrm{pH}, \mathrm{OM} \%$, adsorption forces on soil colloids (humus and clay), $\mathrm{CaCO}_{3} \%$, and the $\mathrm{P}$ concentration in the soil solution, as well as the cropping system and other agricultural practices (Viets 1962; Wei et al. 2006; Li et al. 2007; Ben-Yin et al. 2010; Sachan and Krishna 2018; Das et al. 2017). Soil $\mathrm{pH}$ plays a major role in the availability of micronutrients. For instance, high $\mathrm{pH}$ level is associated with the occurrence of phosphate, lead to iron fixation resulting in iron deficiency symptoms known as iron chlorosis (Mengel 1994). Thus, Fe changes from $\mathrm{Fe}^{2+}$, which is soluble and suitable for vineyards, to $\mathrm{Fe}^{3+}$, which is unsuitable for vineyards cultivation. Similarly, high concentration of manganese, zinc or copper have been linked to weak absorption of iron, especially in acid soils (Mortvedt 1991). Moderate to alkaline $\mathrm{pH}$ levels also affect the availability of $\mathrm{Mn}^{2+}$ in the soil. Alkaline $\mathrm{pH}$ transforms $\mathrm{Mn}^{2+}$ into insoluble $\mathrm{Mn}^{3+}$ (Welch 2003). Zinc $\left(\mathrm{Zn}^{2+}\right)$ availability for vineyards is also related to $\mathrm{pH}$, and many researchers have indicated that zinc deficiency symptoms appear when the soil reaction ranges between 4 and 8 (Barrow 1986); due to precipitation of zinc in the soil. In alkaline soil zinc can be fixed or precipitated by calcium carbonates or iron oxides, while it is fixed by iron and aluminum in low $\mathrm{pH}$ soils. Alloway (2004) reported that the available $\mathrm{Zn}^{2+}$ in the Syrian soil ranges between 0.3 and $3.5 \mathrm{ppm}$. In a similar vein, $\mathrm{Cu}^{2+}$ availability in the studied soil did not exceed the limiting value in most of the profiles, which can be explained by the effect of the $\mathrm{pH}$ level. An inverse relationship was observed between the increased $\mathrm{pH}$ and the availability of Boron in the soil. This finding aligns with Sillanpää (1982), who noted the limited availability of Boron for vineyards in the study area (Table 8).

Mapping of soil properties as well as analyzing the spatial distribution of micronutrient level suitability for vineyards or other crops is essential for achieving sustainable use of soil in vineyards (Barakat et al. 2017). This is because soil mapping helps decision-makers, planners and soil scientists better understand the distribution of these nutrients for them to determine the best management strategies to be adopted in ensuring sustainability of the soil. This is important for the enhancement of crop productivity by identifying areas of deficiency and planning intervention strategies.

\section{Conclusions}

Micronutrient availability for vineyard cultivation was determined on the western slopes of Jabal Al Arab in Syria. The results showed a concentration of micronutrients below the critical deficiency level in most of the studied soil profiles.
Table 8 Distribution of limiting value for micronutrient in the study area

\begin{tabular}{llc}
\hline Micronutrient & Limiting value $(\mathrm{ppm})$ & Area $\mathrm{km}^{2}$ \\
\hline$B(\mathrm{ppm})$ & -35 to -34 & 385.381 \\
& -34 to -33.3 & 133.202 \\
$\mathrm{Fe}(\mathrm{ppm})$ & -26.7 to -20 & 204.48 \\
& -20 to -10.5 & 224.89 \\
& -10.5 to 0 & 75.52 \\
& 0 to 45.5 & 13.68 \\
$\mathrm{Zn}(\mathrm{ppm})$ & -25.9 to -23 & 395.8 \\
& -23 to -19 & 122.7 \\
$\mathrm{Mn}(\mathrm{ppm})$ & -28 to -20 & 175.85 \\
& -20 to -10 & 272.29 \\
& -10 to 0 & 61.78 \\
& 0 to 43.6 & 8.65 \\
$\mathrm{Cu}(\mathrm{ppm})$ & -5.8 to -5 & 189.89 \\
& -5 to -2.5 & 327.94 \\
& -2.5 to 1.8 & 0.74 \\
\hline
\end{tabular}

Maps of micronutrient distribution indicate that most of the study area suffers from an acute level of micronutrients for vineyards cultivation. For sustainable agriculture within the study area, organic fertilizer, as well as humic substances, accompanied by micronutrient fertilizers should be added to the soil, to ensure sufficient amounts for economic vineyard production. However, further research is required to determine other factors that may exacerbate micronutrients deficiency in vineyards within the study area.

Funding Open Access funding provided by University of Debrecen.

\section{Compliance with ethical standards}

Conflict of interest The authors declare no conflict of interest.

Open Access This article is licensed under a Creative Commons Attribution 4.0 International License, which permits use, sharing, adaptation, distribution and reproduction in any medium or format, as long as you give appropriate credit to the original author(s) and the source, provide a link to the Creative Commons licence, and indicate if changes were made. The images or other third party material in this article are included in the article's Creative Commons licence, unless indicated otherwise in a credit line to the material. If material is not included in the article's Creative Commons licence and your intended use is not permitted by statutory regulation or exceeds the permitted use, you will need to obtain permission directly from the copyright holder. To view a copy of this licence, visit http://creativecommons.org/licenses/by/4.0/. 


\section{References}

Abbaspour-Gilandeh M, Abbaspour-Gilandeh Y (2019) Modelling soil compaction of agricultural soils using fuzzy logic approach and adaptive neuro-fuzzy inference system (ANFIS) approaches. Model Earth Syst Environ 5(1):13-20

Abd El-Hamid HT, Hong G (2020) Hyperspectral remote sensing for extraction of soil salinization in the northern region of Ningxia. Model Earth Syst Environ 1-7

Abu Nukta F (1995) Environmental impact of fertilizers uses in Syria. In: El-Fouly MM, Abdalla FE (eds) Proceedings seminar, production and use of chemical fertilizers and environment. Cairo, pp 35-50

Abu Nuqta F, Bat'ha M (2010) The role of fertilization by potassium humate solution in Helwany grape production. Damascus Univ J Agric Sci 26(1):15-31 (in Arabic)

Abu NF, Parkinson R (2007) Effect of humic substances on micronutrients availability in soils. Damascus Univ Agric Sci 23(2):163-178

Abuelgasim A, Ammad R (2019) Mapping soil salinity in arid and semi-arid regions using Landsat 8 OLI satellite data. Remote Sens Appl Soc Environ 13:415-425

Alloway BJ (2004) Zinc in soils and crop nutrition. IZA and IFA Brussels, Belgium and Paris, France

Alloway BJ (2008) Micronutrients and crop production: an introduction. In: Alloway BJ (ed) Micronutrient deficiencies in global crop production. Springer, Amsterdam, pp 1-39. https://doi. org/10.1007/978-1-4020-6860-7_1

Al-Nasseer A, Yaseen M, Fraijat N (2006) Analysis of wholesale prices for Helwani vitis vinifera helwani and baladi grapes $\mathrm{V}$. V. Baladi in AL-Hal's Market in Damascus for the Season 2003. Damascus Univ J Agric Res 22(2):295-314 (in Arabic)

Al-Nasseer A, Yaseen M, Fraijat N, Ismai I (2010) A study of table grape's flow to the Syrian's wholesale market, which sale for export for the period 2006-2008. Drasta Agric Res 37(2):57-66 (in Arabic)

Alsafadi K, Mohammed S, Habib H, Kiwan S, Hennawi S, Sharaf M (2019) An integration of bioclimatic, soil, and topographic indicators for viticulture suitability using multi-criteria evaluation: a case study in the Western slopes of Jabal Al Arab-Syria. Geocarto Int 35:1-23

Al-Youssef W, Muhsen W, Abu-Aljadael R, Alasaad N, Abdullah Altaher F (2017) Detection of the genetic variation among grape rootstock B41 trees in the Syrian agricultural ministry nurseries using SSR markers. Syrian J Agric Res 4(1):19-31 (in Arabic)

Amorós JA, Bravo S, Pérez-de-los-Reyes C, García-Navarro FJ, Campos JA, Sánchez-Ormeño M, Higueras P (2018) Iron uptake in vineyard soils and relationships with other elements $(\mathrm{Zn}$, $\mathrm{Mn}$ and $\mathrm{Ca}$ ). The case of Castilla-La Mancha, Central Spain. Appl Geochem 88:17-22. https://doi.org/10.1016/j.apgeo chem.2017.02.009

Barakat A, Ennaji W, El Jazouli A, Amediaz R, Touhami F (2017) Multivariate analysis and GIS-based soil suitability diagnosis for sustainable intensive agriculture in Beni-Moussa irrigated subperimeter (Tadla plain, Morocco). Model Earth Syst Environ $3(1): 3$

Barrow NJ (1986) Testing a mechanistic model. II. The effects of time and temperature on the reaction of zinc with a soil. J Soil Sci 37(2):277-286

Ben-Yin LI, Huang SM, Ming-Bao WEI, Zhang HL, Jian-Ming XU, Xin-Ling RUAN (2010) Dynamics of soil and grain micronutrients as affected by long-term fertilization in an aquic Inceptisol. Pedosphere 20(6):725-735. https://doi.org/10.1016/S1002 $-0160(10) 60063-X$
Bocchi S, Castrignano A, Fornaro F, Maggiore T (2000) Application of factorial kriging for mapping soil variation at field scale. Eur J Agron 13:295-308

Burns S (2012) The importance of soil and geology in tasting terroir with a case history from the Willamette Valley, Oregon. In: The Geography of Wine. Springer, Dordrecht, pp 95-108. https://doi. org/10.1007/978-94-007-0464-0_6

Chen L, Wang G, Chen P, Zhu H, Wang S, Ding Y (2018) Shoot-root communication plays a key role in physiological alterations of rice (Oryza sativa) under iron deficiency. Front Plant Sci. https://doi. org/10.3389/2Ffpls.2018.00757

Contaldo N, Soufi Z, Bertaccini A, Maini S (2011) Preliminary identification of phytoplasmas associated with grapevine yellows in Syria. Bull Insectol 64(Supplement)

Das J, Gayen A, Saha S, Bhattacharya SK (2017) Modelling of alternative crops suitability to tobacco based on analytical hierarchy process in Dinhata subdivision of Koch Bihar district, West Bengal. Model Earth Syst Environ 3(4):1571-1587

Diodato N, Ceccarelli M (2004) Multivariate indicator kriging approach using a GIS to classify soil degradation for Mediterranean agricultural lands. Ecol Ind 4:177-187

FAO STAT (2018) www.fao.org/faostat/en\#data/QC. Accessed 26 Aug 2018

Geertsema W, Rossing WA, Landis DA, Bianchi FJ, Van Rijn PC, Schaminée JH, Van Der Werf W (2016) Actionable knowledge for ecological intensification of agriculture. Front Ecol Environ 14(4):209-216

George D, Mallery P (2014) IBM SPSS statistics 21 step by step: a simple guide and reference. Pearson

Grossman RB, Reinsch TG (2002) 2.1 Bulk density and linear extensibility. Methods Soil Anal Part 4 Phys Methods 5:201-228

Guan F, Xia M, Tang X, Fan S (2017) Spatial variability of soil nitrogen, phosphorus and potassium contents in Moso bamboo forests in Yong' an City, China. CATENA 150:161-172

Gupta UC (1967) A simplified method for determining hot-watersoluble boron in podzol soils. Soil Sci 103(6):424-428

Helmke PA, Sparks DL (1996) Lithium, sodium, potassium, rubidium, and cesium. Methods Soil Anal Part 3 Chem Methods 5:551-574

Hennawi S, Habib H (2012) The impact of spatial variation on some morphological and chemical properties of some soils from the western slope of Jabal Al Arab. J Damascus Univ Agric Res 28(2):435-454 (in Arabic)

Jalab B, Al-Sallom M (2016) Influence of some iron compounds in the correction of iron deficiency in grape trees, Helwani cultivar. Syrian J Agric Res 3(1):202-2013 (in Arabic)

Kahsay A, Haile M, Gebresamuel G, Mohammed M (2018) GIS-based multi-criteria model for land suitability evaluation of rainfed teff crop production in degraded semi-arid highlands of Northern Ethiopia. Model Earth Syst Environ 4(4):1467-1486

Khademalrasoul A, Amerikhah H (2020) Assessment of soil erosion patterns using RUSLE model and GIS tools (case study: the border of Khuzestan and Chaharmahal Province, Iran). Model Earth Syst Environ 1-11

Khresat SE, Al-Bakri J, Al-Tahhan R (2008) Impacts of land use/cover change on soil properties in the Mediterranean region of northwestern Jordan. Land Degrad Dev 19(4):397-407

Kiwan S, Watfa H, Saleem S (2014) The reality of micronutrients in some soils of the south area of Swaida. J Damascus Univ Agric Res 30(3):134-154 (in Arabic)

Li BY, Zhou DM, Cang L, Zhang HL, Fan XH, Qin SW (2007) Soil micronutrient availability to crops as affected by long-term inorganic and organic fertilizer applications. Soil Tillage Res 96(12):166-173. https://doi.org/10.1016/j.still.2007.05.005

Lindsay WL, Norvell WA (1978) Development of a DTPA soil test for zinc, iron, manganese, and copper. Soil Sci Soc Am J 42(3):421-428 
Liu ZP, Shao MA, Wang YQ (2012) Large-scale spatial interpolation of soil $\mathrm{pH}$ across the Loess Plateau, China. Environ Earth Sci 69:2731-2741

Liu X, Yang T, Wang Q, Huang F, Li L (2018) Dynamics of soil carbon and nitrogen stocks after afforestation in arid and semi-arid regions: a meta-analysis. Sci Total Environ 618:1658-1664

Loeppert RH, Suarez DL (1996) Carbonate and gypsum. Methods Soil Anal Part 3 Chem Methods 5:437-474

MAAR Ministry of agriculture (2016) Area, Number \& Production of Fruitful Trees by Sectors during (2012-2016). Damascus Syria

Mahmoud AWM, Taha SS (2018) Main sulphur content in essential oil of Eruca sativa as affected by nano iron and nano zinc mixed with organic manure. Agriculture (Pol'nohospodárstvo) 64(2):65-79. https://doi.org/10.2478/agri-2018-0007

Makee H, Charbaji T, Ayyoubi Z, Idris I (2004) Evaluating resistance of some rootstocks to grape phylloxera with in vitro and excised root testing systems. In Vitro Cell Dev Biol Plant 40(2):225-229. https://doi.org/10.1079/IVP2003496

Makee H, Charbaji T, Idris I, Ayyoubi Z (2008) Effect of gamma irradiation on survival and reproduction of grape phylloxera Daktulosphaira vitifoliae (Fitch). Adv Hortic Sci 182-186. https://www. jstor.org/stable/42882636

Makee H, Ammounha H, Idris I (2010) Development and reproduction of phylloxera on some local grape varieties in Syria. Adv Hortic Sci 169-175. https://www.jstor.org/stable/42882780

Matson PA, Parton WJ, Power AG, Swift MJ (1997) Agricultural intensification and ecosystem properties. Science 277(5325):504-509

McGregor D, McCoubrey A, Stidwell R (1998) Developing an index of land degradation: some Jamaican examples. Caribb Geogr 9(2):136-147

Melan AO (1982) Methods of soil analysis Part II, 2nd edn. American Society of Agronomy, Madison, p 1159

Mengel K (1994) Iron availability in plant tissues-iron chlorosis on calcareous soils. Plant Soil 165(2):275-283

Mohammed S, Khallouf A, Kiwan S, Alhenawi S, Ali H, Harsányi E, Habib H (2020c) Characterization of major soil orders in Syria. Eurasian Soil Sci 53:420-429

Mohammed S, Alsafadi K, Ali H, Mousavi SMN, Kiwan S, Hennawi S, Anh DT (2020) Assessment of land suitability potentials for winter wheat cultivation by using a multi criteria decision Support-Geographic information system (MCDS-GIS) approach in Al-Yarmouk Basin (S syria). Geocarto Int 1-19

Mohammed S, Habi H, Ali H, Alhenawi S, Kiwan S, Ghanem S, Harsányi E (2020b) Soils of the Southern Syria-A big database for the future land management planning. Data Brief 105832

Mortvedt JJ (1991) Micronutrient fertilizer technology. Micronutr Agric (micronutrientsi) 4:523-548

Nelson DW, Sommers LE (1982) Methods of soil analysis. Part II (2nd edn). Madison, pp 1159

Phachomphon K, Dlamini P, Chaplot V (2010) Estimating carbon stocks at a regional level using soil information and easily accessible auxiliary variables. Geoderma 155:372-380
Polemio M, Rhoades JD (1977) Determining cation exchange capacity: a new procedure for calcareous and gypsiferous soils. Soil Sci Soc Am J 41(3):524-528

Preetha PP, Al-Hamdan AZ (2019) Multi-level pedotransfer modification functions of the USLE-K factor for annual soil erodibility estimation of mixed landscapes. Model Earth Syst Environ 5(3):767-779

Rhoades JD (1982) Cation exchange capacity. In: Page AL, Miller RH, Keeney DR (eds) Methods of soil analysis, part 2; chemical and microbiological properties, 2nd edn. American Society of Agronomy, Madison, pp 149-158

Robinson T, Metternicht G (2006) Testing the performance of spatial interpolation techniques for mapping soil properties. Comput Electron Agric 50:97-108

Rojas RV, Achouri M, Maroulis J, Caon L (2016) Healthy soils: a prerequisite for sustainable food security. Environ Earth Sci 75(3): 180

Sachan HK, Krishna D (2018) Estimating micronutrient status and their relationship with other soil properties of Rewa District in Fiji. Int J Curr Microbiol Appl Sci 7(01):2808-2812. https://doi. org/10.20546/ijcmas.2018.701.335

Sillanpää M (1982) Micronutrients and the nutrient status of soil: a global study. FAO Soils Bull 48:323-331

Suarez DL (1996) Beryllium, magnesium, calcium, strontium, and barium. Methods Soil Anal Part 3 Chem Methods 5:575-601

Sys IC, Van Ranst B, Debaveye J (1991) Land Evaluation. Part I. Principles in land Evaluation and Crop Production Calculations. International training Center for post graduate soil scientists, University Ghent

Uygur V, Irvem A, Karanlik S, Akis R (2010) Mapping of total nitrogen, available phosphorous and potassium in Amik Plain, Turkey. Environ Earth Sci 59:1129-1138

Viets FG Jr (1962) Micronutrient availability, chemistry and availability of micronutrients in soils. J Agric Food Chem 10(3):174-178. https://doi.org/10.1021/jf60121a004

Wei X, Hao M, Shao M, Gale WJ (2006) Changes in soil properties and the availability of soil micronutrients after 18 years of cropping and fertilization. Soil Tillage Res 91(1-2):120-130

Welch RM (2003) Farming for nutritious foods: Agricultural technologies for improved human health. In: IFA-FAO Agricultural Conference, Rome, Italy

White RE (2009) Understanding vineyard soils. Oxford University Press, Oxford, p 230. https://doi.org/10.2136/vzj2010.0084br

Wubie MA, Assen M (2020) Effects of land cover changes and slope gradient on soil quality in the Gumara watershed, Lake Tana basin of North-West Ethiopia. Model Earth Syst Environ 6(1):85-97

Publisher's Note Springer Nature remains neutral with regard to jurisdictional claims in published maps and institutional affiliations. 